\title{
Gaseous emissions from outdoor concrete yards used by livestock
}

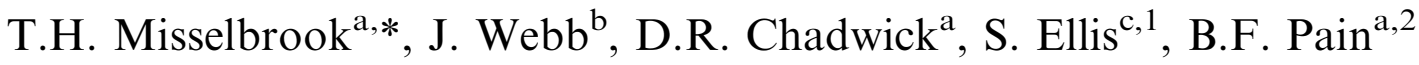 \\ ${ }^{\mathrm{a}}$ Institute of Grassland and Environmental Research, North Wyke, Okehampton, Devon EX20 2SB, UK \\ b ADAS Research, Wergs Road, Wolverhampton WV6 8TQ, UK \\ ${ }^{\mathrm{c}}$ ADAS Boxworth, Battlegate Lane, Boxworth, Cambridge CB2 $3 N N$, UK
}

Received 29 November 2000; received in revised form 15 May 2001; accepted 21 May 2001

\begin{abstract}
Measurements of ammonia $\left(\mathrm{NH}_{3}\right)$, nitrous oxide $\left(\mathrm{N}_{2} \mathrm{O}\right)$ and methane $\left(\mathrm{CH}_{4}\right)$ were made from 11 outdoor concrete yards used by livestock. Measurements of $\mathrm{NH}_{3}$ emission were made using the equilibrium concentration technique while closed chambers were used to measure $\mathrm{N}_{2} \mathrm{O}$ and $\mathrm{CH}_{4}$ emissions. Outdoor yards used by livestock proved to be an important source of $\mathrm{NH}_{3}$ emission. Greatest emission rates were measured from dairy cow feeding yards, with a mean of $690 \mathrm{mg} \mathrm{NH} \mathrm{NH} \mathrm{m}_{3}^{-2} \mathrm{~h}^{-1}$. Smaller emission rates were measured from sheep handling areas, dairy cow collecting yards, beef feeding yards and a pig loading area, with respective mean emission rates of 440, 280, 220 and $140 \mathrm{mg} \mathrm{NH}_{3^{-}}$ $\mathrm{Nm}^{-2} \mathrm{~h}^{-1}$. Emission rates of $\mathrm{N}_{2} \mathrm{O}$ and $\mathrm{CH}_{4}$ were much smaller and for $\mathrm{CH}_{4}$, in particular, emission rates were influenced greatly by the presence or absence of dung on the measurement area. (C) 2001 Elsevier Science Ltd. All rights reserved.
\end{abstract}

Keywords: Ammonia emission; Nitrous oxide; Methane; Concrete yards

\section{Introduction}

Most livestock farms in the UK, and dairy farms in particular, have outdoor, unroofed, concrete yard areas for handling and feeding of livestock. Fouling of such areas with urine and faeces may lead to emission of gases of environmental concern such as ammonia $\left(\mathrm{NH}_{3}\right)$, implicated in eutrophication of fragile ecosystems and soil acidification, nitrous oxide $\left(\mathrm{N}_{2} \mathrm{O}\right)$ and methane $\left(\mathrm{CH}_{4}\right)$, both greenhouse gases. Work by Misselbrook

\footnotetext{
*Corresponding author. Tel.: +44-1837-883500; fax: +441837-82139.

E-mail address: tom.misselbrook@bbsrc.ac.uk (T.H. Misselbrook).

${ }^{1}$ Present address: Rural, Marine and Environment Division, MAFF, Nobel House, 17 Smith Square, London SW1P 3JR, UK.

${ }^{2}$ Present address: Lamorna, Sandford, Crediton, Devon EX17 4LN, UK.
}

et al. (1998) showed dairy cow collecting yards to be an important source of $\mathrm{NH}_{3}$ emission and other yard areas fouled by livestock are also likely to be significant sources. There are currently no estimates of emissions of either $\mathrm{N}_{2} \mathrm{O}$ or $\mathrm{CH}_{4}$ from such areas.

There is little published research relating to emissions from outdoor concrete yards used by livestock. However, there is a growing body of research relating to $\mathrm{NH}_{3}$ emissions from the floors of livestock housing which, as the processes leading to emission are the same, are relevant to this study. Ammonia emissions will be, primarily, from the urea content of urine deposits, with possibly a small proportion from faeces (Whitehead, 1995). After deposition on the concrete surface, urea is hydrolysed to $\mathrm{NH}_{3}$ by the ubiquitous enzyme urease, which is produced by microorganisms present in faeces. Emission of this ammonia to the atmosphere will subsequently occur, the rate of which will depend on factors affecting the equilibria between $\mathrm{NH}_{3} / \mathrm{NH}_{4}^{+}$in solution and between dissolved and gaseous $\mathrm{NH}_{3}$. 
Monteny and Erisman (1998), in a review of research on emissions from dairy cow buildings, concluded that the important influencing parameters were urea concentration of the urine, urease activity, $\mathrm{pH}$, temperature, air velocity and floor area. Rainfall and efficiency of yard cleaning might be two additional factors important for outdoor yard areas.

Nitrous oxide emissions from agriculture derive from the processes of nitrification and denitrification (Egginton and Smith, 1986), with denitrification generally accepted as being the major source. These processes are dependent primarily on soil-based microbial populations and a source of readily available carbon. The requirement for both nitrification (an aerobic process), followed by denitrification (an anaerobic process), is the presence of the necessary microbial populations and a readily available carbon substrate mean that conditions on concrete yards fouled by livestock are unlikely to be conducive to nitrous oxide emission, unless there are areas of substantial dirt build-up.

Over $90 \%$ of $\mathrm{CH}_{4}$ emissions from UK agriculture derive from enteric fermentation in cattle and sheep (Chadwick et al., 1999). However, freshly voided dung from grazing animals has the potential for $\mathrm{CH}_{4}$ emission as it carries the appropriate organisms (Dar and Tandon, 1987), therefore, dung pats on hard standings are a potential source of methane if left in situ. Methane production is also an anaerobic process and will therefore only occur if suitable conditions exist.

The aim of the present study was to measure the emission rates of $\mathrm{NH}_{3}, \mathrm{~N}_{2} \mathrm{O}$ and $\mathrm{CH}_{4}$ from a range of outdoor concrete yards used by livestock.

\section{Materials and methods}

\subsection{Site details}

Gaseous emission measurements were made from 11 outdoor concrete livestock yards located on farms in the Midlands and South West England between September 1997 and January 2000. At each site, the area of the yard was measured and information about the number of animals using the area and frequency of use was obtained. Also, information on cleaning method and frequency was gathered (Table 1). During the first year, dairy cow collecting yards were the focus of measurements. During the second and third years, measurements were made from dairy cow feeding yards, beef cattle feeding/loafing yards, sheep handling areas and a pig loading area.

\subsection{Gaseous emission measurements}

Measurements of $\mathrm{NH}_{3}$ emissions were made using the equilibrium concentration technique employing a system of small dynamic chambers (Svensson, 1994). The equilibrium concentration method uses the micrometeorological law of resistance to determine the flux of $\mathrm{NH}_{3}\left(\Phi_{\mathrm{NH}_{3}}, \mu \mathrm{g} \mathrm{m}{ }^{-2} \mathrm{~s}^{-1}\right)$ from an emitting surface from the equilibrium concentration of $\mathrm{NH}_{3}$ in the air at the emitting surface $\left(C_{\text {eq }}, \mu \mathrm{g} \mathrm{m}^{-3}\right)$, the $\mathrm{NH}_{3}$ concentration in the air above the emitting surface $\left(C_{\mathrm{a}}, \mu \mathrm{g} \mathrm{m}^{-3}\right)$ and the mass transfer coefficient for $\mathrm{NH}_{3}$ $\left(K_{\mathrm{a}}, \mathrm{m} \mathrm{s}^{-1}\right)$ :

$\Phi_{\mathrm{NH}_{3}}=\left(C_{\text {eq }}-C_{\mathrm{a}}\right) K_{\mathrm{a}}$.

Passive diffusion samplers (impregnated with $2 \%$ tartaric acid) were used to determine $\mathrm{NH}_{3}$ concentration in the air. Samplers were used within small dynamic chambers to determine $C_{\text {eq }}$, and also exposed outside the chambers to determine $C_{\mathrm{a}}$. $K_{\mathrm{a}}$ was determined using two samplers of differing diffusion path length.

Emission rates of $\mathrm{N}_{2} \mathrm{O}$ and $\mathrm{CH}_{4}$ were measured using either a system of closed chambers (Mosier, 1989) with analysis by gas chromatography or using recirculating closed-chambers with photo-acoustic detection (Velthof et al., 1996). Gas samples were taken from each chamber at regular intervals within the sampling period (of up to $48 \mathrm{~min}$ ) and emission rate was calculated from the linear increase in concentration over time per unit surface area covered by the chamber.

For a particular measurement site, 4-6 chambers (together with 3-6 ambient samplers for $\mathrm{NH}_{3}$ ) were used for $\mathrm{NH}_{3}, \mathrm{~N}_{2} \mathrm{O}$ and $\mathrm{CH}_{4}$ emission measurements, with chambers positioned randomly across the area. Typically, at each sampling date there were 3-6 periods when gaseous emission measurements would be made from each chamber. For $\mathrm{NH}_{3}$, sampling times were $1-2 \mathrm{~h}$, or occasionally longer when very low emission rates were expected. Between sampling periods, chambers were removed from the yard surface, but replaced in the same position during subsequent periods so that changes in emission with time, particularly due to scraping events or animal usage, could be assessed. Animals were excluded from the yard during sampling periods to prevent damage to the equipment. Measurements were conducted over a $24 \mathrm{~h}$ period on dairy cow collecting yards on three occasions to assess diurnal variation in emissions. For hard standings, used less frequently (e.g. sheep handling and pig loading areas), measurement commenced after removal of the animals and continued for up to $2 \mathrm{~d}$. Air temperature and wind speed were also recorded. Urine and faecal deposits on the yards were not measured, but some estimates were made of urine and urea-N deposits using data derived from Whitehead (1995).

\subsection{Statistical analysis}

The lack of a true experimental design precluded a detailed statistical analysis of the results. However, 
Table 1

Measurement sites

\begin{tabular}{|c|c|c|c|c|c|}
\hline Site & Yard type & Location & $\begin{array}{l}\text { Area } \\
\left(\mathrm{m}^{2}\right)\end{array}$ & $\begin{array}{l}\text { No. of animals } \\
\text { using yard }\end{array}$ & $\begin{array}{l}\text { Cleaning method/ } \\
\text { frequency }\end{array}$ \\
\hline 1 & Dairy cow collecting yard & Shropshire & 150 & 135 & Scraped daily \\
\hline 2 & Dairy cow collecting yard & Nottinghamshire & 200 & 240 & Scraped daily \\
\hline 3 & Dairy cow collecting yard & Devon & 82 & 85 & Scraped daily \\
\hline 4 & Dairy cow feeding/loafing yard & Devon & 156 & 85 & $\begin{array}{l}\text { Scraped daily in winter, } \\
\text { weekly in summer }\end{array}$ \\
\hline 5 & Dairy cow feeding/loafing yard & Shropshire & 150 & 135 & Infrequent scraping \\
\hline 6 & Beef cattle feeding/loafing yard & Devon & 225 & 10 & Scraped weekly \\
\hline 7 & Beef cattle feeding/loafing yard & Devon & 94 & 47 & Scraped weekly \\
\hline 8 & Beef cattle feeding/loafing yard & Shropshire & 210 & 20 & Scraped weekly \\
\hline 9 & Sheep handling area & Devon & 90 & 75 & Not cleaned \\
\hline 10 & Sheep handling area & Shropshire & 70 & 600 & Not cleaned \\
\hline 11 & Pig loading area & Shropshire & 125 & 55 & Not cleaned \\
\hline
\end{tabular}

Table 2

Mean $\mathrm{NH}_{3}$ emission rate $\left(\mathrm{mg} \mathrm{NH} \mathrm{NH}_{3}-\mathrm{N} \mathrm{m}^{-2} \mathrm{~h}^{-1}\right)$ measured from each site and for each yard type ${ }^{\mathrm{a}}$

\begin{tabular}{|c|c|c|c|c|}
\hline Site & Yard type & $\begin{array}{l}\text { Mean emission rate } \\
\left(\mathrm{mg} \mathrm{NH}_{3}-\mathrm{N} \mathrm{m}^{-2} \mathrm{~h}^{-1}\right)\end{array}$ & No. of observations & $\begin{array}{l}\text { Mean emission rate for yard } \\
\text { type }\left(\mathrm{mg} \mathrm{NH}_{3}-\mathrm{N} \mathrm{m}^{-2} \mathrm{~h}^{-1}\right)\end{array}$ \\
\hline 1 & Dairy cow collecting yard & 480 & 218 & $280 \mathrm{ab}$ \\
\hline 2 & Dairy cow collecting yard & 200 & 88 & \\
\hline 3 & Dairy cow collecting yard & 180 & 378 & \\
\hline 4 & Dairy cow feeding yard & 410 & 42 & $690 \mathrm{c}$ \\
\hline 5 & Dairy cow feeding yard & 1070 & 30 & \\
\hline 6 & Beef feeding/loafing area & 30 & 35 & \\
\hline 7 & Beef feeding/loafing area & 170 & 18 & $220 \mathrm{a}$ \\
\hline 8 & Beef feeding/loafing area & 430 & 36 & \\
\hline 9 & Sheep handling area & 250 & 62 & $440 \mathrm{~b}$ \\
\hline 10 & Sheep handling area & 690 & 48 & \\
\hline 11 & Pig loading area & 140 & 138 & $140 \mathrm{a}$ \\
\hline s.e.d. & & & & 93 \\
\hline$P$ & & & & $<0.001$ \\
\hline
\end{tabular}

${ }^{\text {a }}$ Values with different letters are significantly different $(P<0.05)$.

analysis of variance (using the GENSTAT statistical package) was conducted to compare mean emission rates from the different yard types and, within sites, to look for seasonal effects. Regression analysis was used to examine the effect of temperature and wind speed on emission rates.

\section{Results}

\subsection{Ammonia emissions}

Mean $\mathrm{NH}_{3}$ emission rates for each of the 11 sites are given in Table 2, together with mean rates for each type of yard. Similar emission rates were measured from the three dairy cow collecting yards. Emission rates were significantly greater from the dairy cow feeding yards than from other yard types, reflecting the less efficient removal of dung and urine and, generally, the greater time spent by animals on these yards (particularly during the winter months, when animals would spend the majority of the day on the area). Emission rates from beef feeding/loafing yards were less than those from dairy cow feeding yards, but similar to the rates from dairy cow collecting yards. For site 6 , where only 10 animals had access to a yard of $225 \mathrm{~m}^{2}$ and also access to a field at the time of measurement, extremely small emission rates were measured. There were differences in the emission rates measured from the two sheep handling areas. This is not surprising, since site 10 , with the greater emission, had 600 sheep on an area of $70 \mathrm{~m}^{2}$ for a $2 \mathrm{~h}$ period, whereas for site 9 , there 
were 75 sheep on a $90 \mathrm{~m}^{2}$ area for a $4 \mathrm{~h}$ period. Again, emission rates were similar to those from dairy cow collecting yards. The smallest mean emission rate (although not significantly different from rates from dairy cow collecting yards or beef feeding/loafing yards) was measured from a pig loading area, where the pigs were present for $1 \mathrm{~h}$.

For most sites, insufficient measurements were made to examine any possible seasonal effects on emission rates. However, results from site 3 (six chambers used on each occasion), which represents the largest data set, showed no significant seasonal effects $(P>0.05)$ on emission rate (Fig. 1). In addition, across all sites, regression analysis revealed no significant relationships $(P>0.05)$ between emission rate and either temperature or wind speed.

The diurnal variation in emission rate for two measurement occasions (both on dairy cow collecting yards, sites 1 and 3 , respectively) where measurements continued over $24 \mathrm{~h}$ is shown in Fig. 2. The error bars give an indication of the variation in measured emission rate between chambers (each point being the mean of six chambers) across a yard, due to the heterogeneous nature of urine and faecal deposits. Both sets of diurnal measurements began after the yard was scraped after morning milking. At both sites, emission rate then decreased steadily throughout the day until cows returned to the yard prior to evening milking. This effect, although expected, was not consistently observed in all measurements, with the both increases and constant emission rates measured throughout the day. Emission rates then peaked again following the evening milking, declined overnight with some evidence of an increase in the early morning at site 1 and an increase following morning milking again at site 3 . There was no significant difference between mean emission rates measured during the daytime or overnight.

Although no samples were taken for analysis, estimates of the urea-N input to each hard standing (from which the $\mathrm{NH}_{3}$ emission principally derives) were made using literature-derived values for urine production and urea-N concentration (Whitehead, 1995) and best estimates of time spent by animals on each yard. Urea-N input per animal to the yard was calculated as the product of urea-N concentration of urine, volume of urine produced per day and proportion of day spent by animals on the yard (Table 3). This was converted to urea-N input per $\mathrm{m}^{2}$ for each yard, using the yard areas and animal usage given in Table 1. The mean loss from each yard (Table 2), expressed as \% of the estimated urea-N deposited, varied from $14 \%$ for one of the beef feeding areas to $200 \%$ for one of the sheep handling areas. There is a wide range of uncertainty in both the urea- $\mathrm{N}$ concentrations and volume of urine produced per animal per day and in the estimate of daily usage of yards by livestock and therefore, large uncertainty in the losses expressed as \% inputs. However, these values would tend to confirm the measured emission rates as being reasonable.

\subsection{Nitrous oxide and methane emissions}

Emission rates for $\mathrm{N}_{2} \mathrm{O}$ and $\mathrm{CH}_{4}$ were smaller than $\mathrm{NH}_{3}$ (Tables 4 and 5). For $\mathrm{N}_{2} \mathrm{O}$, highest emission rates
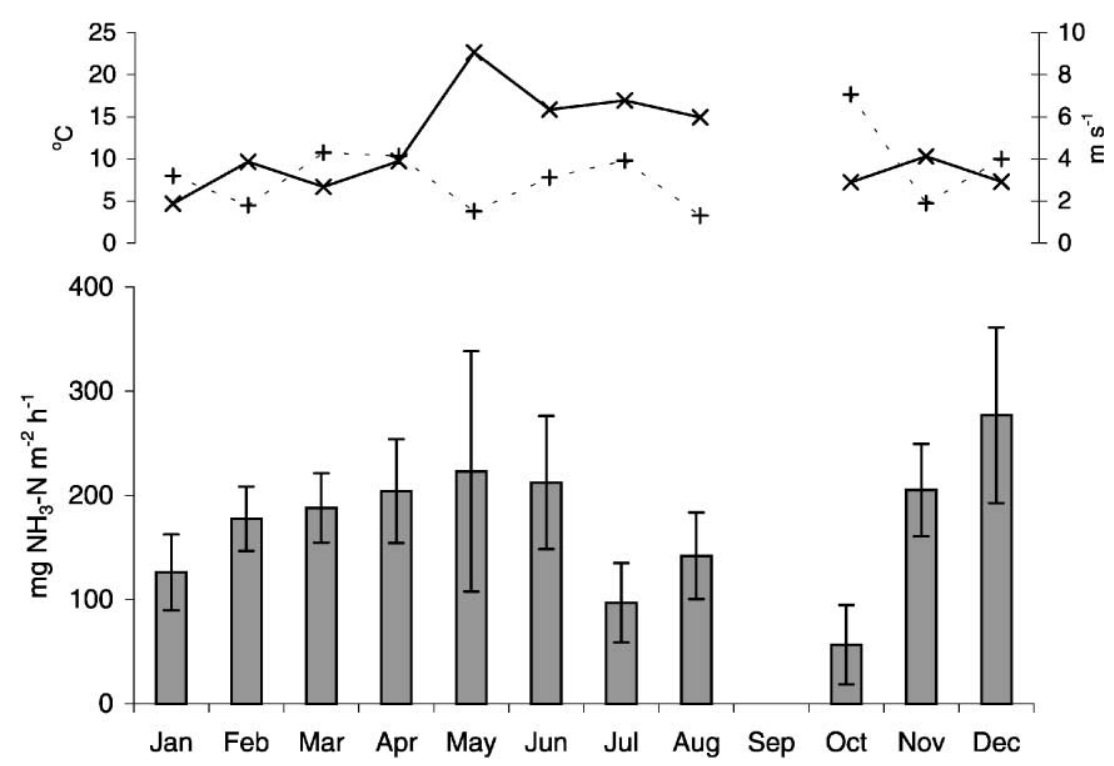

Fig. 1. Mean emission rates, together with mean daily temperature $(x)$ and wind speed $(+)$ for the measurement dates, for a dairy cow collecting yard (site 3). Error bars are for the standard error of the mean value. 
(a)
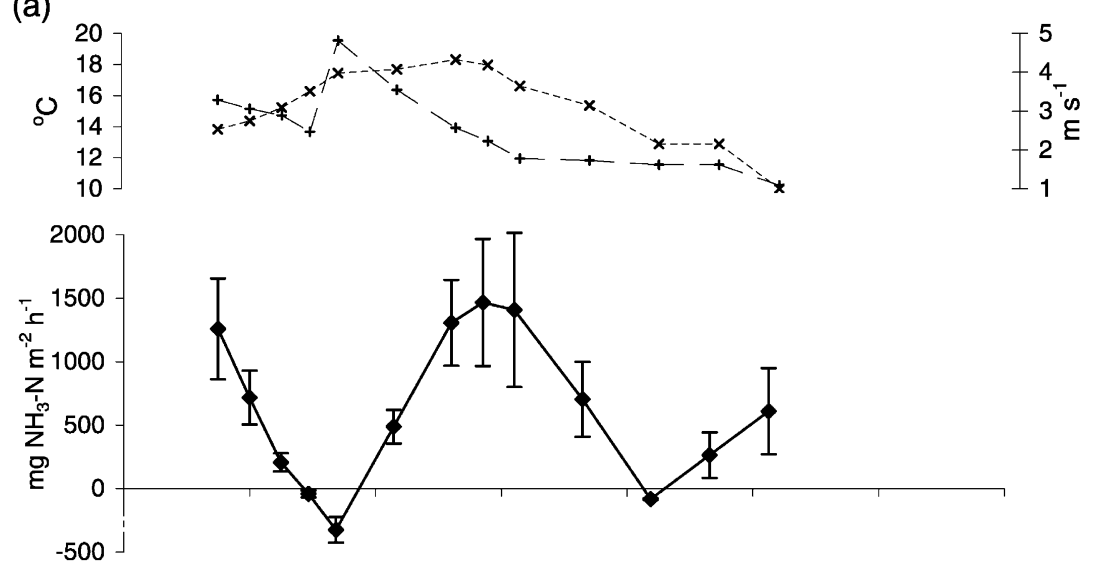

(b)
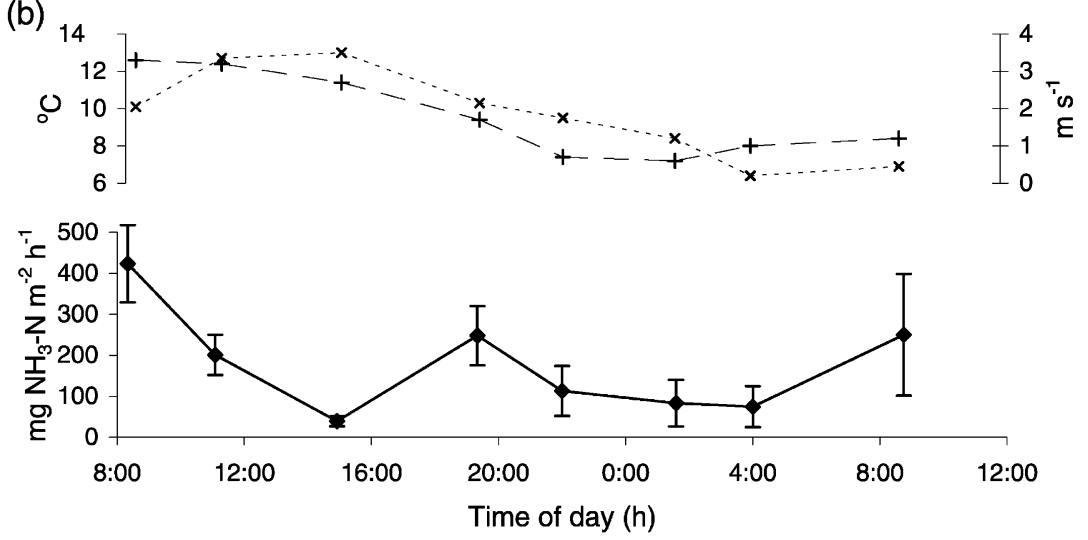

Fig. 2. Examples of diurnal variation in emission of ammonia $\left(\mathrm{g} \mathrm{NH}_{3}-\mathrm{N} \mathrm{m}^{-2} \mathrm{~h}^{-1}\right)$ from dairy cow collecting yards, together with mean temperature $(x)$ and wind speed $(+)$ for each sampling period. Sites 1(a) and 3(b), with measurements conducted in August and December, respectively. Error bars are for standard error of the mean value (six observations).

Table 3

Estimated urea-N deposited on outdoor yards used by livestock ${ }^{\mathrm{a}}$

\begin{tabular}{|c|c|c|c|c|c|c|c|}
\hline \multirow[t]{2}{*}{ Yard type } & \multirow{2}{*}{$\begin{array}{l}\text { Urine urea-N } \\
\text { concentration } \\
\left(\mathrm{g} \mathrm{l}^{-1}\right)\end{array}$} & \multirow{2}{*}{$\begin{array}{l}\text { Urine } \\
\text { production } \\
\left(\text { l animal }^{-1} \mathrm{~d}^{-1}\right)\end{array}$} & \multirow{2}{*}{$\begin{array}{l}\text { Time spent by } \\
\text { animals on yard } \\
h\end{array}$} & \multicolumn{3}{|c|}{ Urea-N deposited to yard } & \multirow{2}{*}{$\begin{array}{l}\text { Loss as } \% \\
\text { urea-N deposited }\end{array}$} \\
\hline & & & & site & $\left(\right.$ g animal $\left.^{-1} \mathrm{~d}^{-1}\right)$ & $\left(\mathrm{g} \mathrm{m}^{-2} \mathrm{~d}^{-1}\right)$ & \\
\hline \multirow[t]{3}{*}{ Dairy cow collecting yard } & $7.2(1.6-16)$ & $25(10-40)$ & 2 & 1 & 15 & 13.5 & 85 \\
\hline & $7.2(1.6-16)$ & $25(10-40)$ & 2 & 2 & 15 & 18.0 & 27 \\
\hline & $7.2(1.6-16)$ & $25(10-40)$ & 2 & 3 & 15 & 15.5 & 28 \\
\hline \multirow[t]{2}{*}{ Dairy cow feeding yard } & $7.2(1.6-16)$ & $25(10-40)$ & 5 & 4 & 38 & 49.0 & 48 \\
\hline & $7.2(1.6-16)$ & $25(10-40)$ & 5 & 5 & 38 & 81.0 & 76 \\
\hline \multirow[t]{3}{*}{ Beef cattle feeding yard } & $7.2(1.6-16)$ & $25(10-40)$ & 8 & 6 & 60 & 4.0 & 27 \\
\hline & $7.2(1.6-16)$ & $25(10-40)$ & 8 & 7 & 60 & 45.0 & 14 \\
\hline & $7.2(1.6-16)$ & $25(10-40)$ & 8 & 8 & 60 & 8.6 & 181 \\
\hline \multirow[t]{2}{*}{ Sheep handling area } & $7.2(4-12)$ & $3(1-7)$ & 4 & 9 & 3.6 & 3.0 & 200 \\
\hline & $7.2(4-12)$ & $3(1-7)$ & 2 & 10 & 1.8 & 15.4 & 108 \\
\hline
\end{tabular}

${ }^{a}$ Values in parentheses are derived from Whitehead (1995). 
Table 4

Mean $\mathrm{N}_{2} \mathrm{O}$ emission rate $\left(\mu \mathrm{g} \mathrm{N}_{2} \mathrm{O}-\mathrm{N} \mathrm{m}^{-2} \mathrm{~h}^{-1}\right)$ measured from each site and for each yard type ${ }^{\mathrm{a}}$

\begin{tabular}{|c|c|c|c|c|}
\hline Site & Yard type & $\begin{array}{l}\text { Mean emission rate } \\
\left(\mu \mathrm{g} \mathrm{N}_{2} \mathrm{O}-\mathrm{N} \mathrm{m}^{-2} \mathrm{~h}^{-1}\right)\end{array}$ & $\begin{array}{l}\text { No. of } \\
\text { observations }\end{array}$ & $\begin{array}{l}\text { Mean emission rate for yard } \\
\text { type }\left(\mu \mathrm{g} \mathrm{N}_{2} \mathrm{O}-\mathrm{N} \mathrm{m}^{-2} \mathrm{~h}^{-1}\right)\end{array}$ \\
\hline 1 & Dairy cow collecting yard & 15.0 & 78 & $7.5 \mathrm{a}$ \\
\hline 2 & Dairy cow collecting yard & 2.9 & 78 & \\
\hline 3 & Dairy cow collecting yard & 6.0 & 192 & \\
\hline 4 & Dairy cow feeding yard & 12.6 & 42 & $18.6 b$ \\
\hline 5 & Dairy cow feeding yard & 39.3 & 12 & \\
\hline 6 & Beef feeding/loafing area & 4.4 & 18 & $10.2 \mathrm{ac}$ \\
\hline 7 & Beef feeding/loafing area & 18.4 & 18 & \\
\hline 8 & Beef feeding/loafing area & 3.4 & 6 & \\
\hline 9 & Sheep handling area & 7.0 & 30 & $17.7 \mathrm{bc}$ \\
\hline 10 & Sheep handling area & 35.4 & 18 & \\
\hline 11 & Pig loading area & 6.1 & 54 & $6.1 \mathrm{a}$ \\
\hline s.e.d. & & & & 4.16 \\
\hline $\mathrm{P}$ & & & & 0.005 \\
\hline
\end{tabular}

${ }^{\text {a }}$ Values with different letters are significantly different $(P<0.05)$.

Table 5

Mean $\mathrm{CH}_{4}$ emission rate $\left(\mathrm{mg} \mathrm{CH}_{4} \mathrm{~m}^{-2} \mathrm{~h}^{-1}\right)$ measured from each site and for each yard type

\begin{tabular}{cllcc}
\hline Site & Yard type & $\begin{array}{l}\text { Mean emission rate } \\
\left(\mathrm{mg} \mathrm{CH} \mathrm{m}^{-2} \mathrm{~h}^{-1}\right)\end{array}$ & $\begin{array}{l}\text { No. of } \\
\text { observations }\end{array}$ & $\begin{array}{l}\text { Mean emission rate for yard } \\
\text { type }\left(\mathrm{mg} \mathrm{CH}_{4} \mathrm{~m}^{-2} \mathrm{~h}^{-1}\right)\end{array}$ \\
\hline 1 & Dairy cow collecting yard & 0.69 & 78 & $0.43 \mathrm{a}$ \\
2 & Dairy cow collecting yard & 0.33 & 78 & $0.36 \mathrm{ab}$ \\
3 & Dairy cow collecting yard & 0.36 & 192 & $0.59 \mathrm{a}$ \\
4 & Dairy cow feeding yard & 0.41 & 42 & $0.12 \mathrm{~b}$ \\
5 & Dairy cow feeding yard & 0.20 & 12 & $0.16 \mathrm{~b}$ \\
6 & Beef feeding/loafing area & 0.13 & 18 & 0.134 \\
7 & Beef feeding/loafing area & 0.63 & 6 & 0.012 \\
8 & Beef feeding/loafing area & 1.77 & 30 & 18 \\
9 & Sheep handling area & 0.03 & 54 & \\
10 & Sheep handling area & 0.26 & & \\
P.e.d. & Pig loading area & 0.16 & & \\
\hline
\end{tabular}

${ }^{a}$ Values with different superscripts are significantly different $(P<0.05)$.

were measured from dairy cow feeding yards and sheep handling areas, although the mean values for these yard types were influenced greatly by one site of each type (sites 5 and 10) with mean emission rates from all other sites being similar regardless of yard type. Emission rates for $\mathrm{CH}_{4}$ were greatest from beef feeding/loafing yards, but, again, this was because of much greater emission rates measured at one site (site 8), with rates measured at all other sites being similar in magnitude. As with $\mathrm{NH}_{3}$, there was little evidence of a seasonal effect in emission rates, although there was some suggestion from the data of greater $\mathrm{N}_{2} \mathrm{O}$ emission rates from dairy cow collecting yards in winter. For both $\mathrm{N}_{2} \mathrm{O}$ and $\mathrm{CH}_{4}$, there was evidence of an increase in emission rates throughout the day, related to increases in temperature. For $\mathrm{CH}_{4}$ in particular, emission rates were also influenced greatly by the presence or absence of dung on the measurement area. This is illustrated in Fig. 3 (data from site 3, February measurement), where emission rates were small after yard scraping in the morning, but increased dramatically in areas covered by dung after the cows had been on the yard prior to afternoon milking.

\section{Discussion}

In this study, the equilibrium concentration technique was used in preference to the Lindvall hood technique, as used by Misselbrook et al. (1998), as it measures emission under ambient conditions, rather than with 


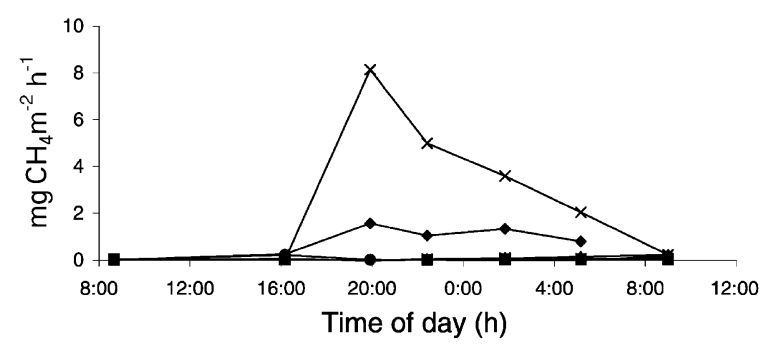

Fig. 3. Example of methane emission from a dairy cow collecting yard (Site 3). Measurements from six chambers, two of which $(x$ and $\bullet$ ) were placed over dung pats.

forced ventilation. The technique has been shown to give similar results to a standard micrometeorological mass balance technique for emissions of $\mathrm{NH}_{3}$ from urea fertiliser and animal manure applied to land (Misselbrook and Hansen, 2001). Additional advantages of the method were that several measurements could be conducted simultaneously, equipment was easily moved between sites and mains electricity was not required. The $\mathrm{NH}_{3}$ emission rates from dairy cow collecting yards, reported here, are in general agreement with values given by Misselbrook et al. (1998), who reported a mean emission rate of $210 \mathrm{mg} \mathrm{NH}_{3}-\mathrm{N} \mathrm{m}^{-2} \mathrm{~h}^{-1}$ for a series of summer and winter measurements on a single yard.

Misselbrook et al. (1998) reported a large seasonal effect, with much greater emission rates in the summer, which they attributed to a combination of higher ambient temperatures and a greater urea- $\mathrm{N}$ concentration of the dairy cattle urine in the summer (presumably due to dietary differences). Keck (1997), using wind tunnels to measure $\mathrm{NH}_{3}$ emissions from urine and faeces applied on concrete surfaces, also reported increased emissions during warmer conditions. No such seasonal effect was evident from the results reported here. Urea-N concentrations in urine were not measured, but they may have varied much less in this study. Theory, and research elsewhere (Elzing and Monteny, 1997; Monteny et al., 1998), show that temperature and wind speed are important factors influencing $\mathrm{NH}_{3}$ emission from urine deposits on concrete floors. The lack of a significant relationship in this study does not necessarily contradict this, as other important influencing factors, which were neither controlled nor measured in this study, may have obscured such relationships. Such factors include the amount of urine and faeces deposited on the yard, urease activity and the efficiency of removal of urine and faeces, generally by scraping, the effectiveness of which may be influenced by rainfall. Data from Misselbrook et al. (1998) suggested that washing rather than scraping the yard reduced subsequent emissions. Keck (1997) found no significant difference in $\mathrm{NH}_{3}$ emissions whether the yard was cleaned daily or every $3 \mathrm{~d}$. However, the measurements were made from yard areas to which cattle had continual access, therefore fresh urine and faeces were being deposited continually, in contrast to dairy cattle collecting yards which, once cleaned, would not receive any fresh urine or faeces for several hours. Airoldi et al. (2000) reported that more frequent manure removal (daily as opposed to weekly or monthly) was extremely important when trying to reduce $\mathrm{NH}_{3}$ emissions from dairy cattle exercise yards. One possible reason for the lack of a consistent pattern of diurnal variation may be the opposing trends of a decreasing emission rate from the thin film of slurry (after scraping) due to source depletion and an increasing emission rate with increasing temperature and wind speed.

As expected, $\mathrm{N}_{2} \mathrm{O}$ emission rates were small, reflecting the unsuitability of conditions existing on concrete yards for any significant nitrification/denitrification to occur. Methane emission rates were very much associated with dung pats (Fig. 3), where anaerobic conditions required by the methanogenic bacteria existed. A thin film of excreta over the yard surface, such as that might exist after yard scraping, would be much less conducive to $\mathrm{CH}_{4}$ emission. The emission rates measured from the dung pats were similar to those reported by Yamulki et al. (1999), measured from dung pats deposited to pasture.

Future research should focus on $\mathrm{NH}_{3}$ emissions, as outdoor concrete yards appear to be an important source that may not be properly accounted for in national emission inventories. Further measurements on a greater number and variety of farms are required to confirm the emission factors given in this paper. More detailed studies would confirm the relative importance of urease activity, temperature, wind speed, urea concentration and volume of urine deposited as factors influencing emission. Possible abatement strategies could include improved cleaning of yards by washing (Braam et al., 1997; Misselbrook et al., 1998), use of urease inhibitors (Varel et al., 1997) and reducing the yard area allowance per animal.

\section{Acknowledgements}

The authors would like to thank D. Headon and S. Upchurch for technical assistance. The work was funded by UK Ministry of Agriculture Fisheries and Food. IGER is sponsored by the Biological and Biotechnological Research Council.

\section{References}

Airoldi, G., Balsari, P., Gioelli, F., 2000. Ammonia emissions from dairy cattle exercise areas. Proceedings of the Ninth International Workshop of the FAO ESCORENA 
Network on Recycling of Agricultural, Municipal and Industrial Residues in Agriculture, Gargnano, Italy, 6-9 September.

Braam, C.R., Ketelaars, J., Smits, M.C.J., 1997. Effects of floor design and floor cleaning on ammonia emission from cubicle houses for dairy cows. Netherlands Journal of Agricultural Science 45, 49-64.

Chadwick, D., Pain, B., Sneath, R., Phillips, V., 1999. Methane and nitrous oxide emissions from UK agricultural livestock. In: Martinez, J., Maudet, M.-N. (Eds.), Proceedings of the Eighth International Conference of the FAO ESCORENA Network on Recycling of Agricultural, Municipal and Industrial Residues in Agriculture. FAO and Cemagref, Antony, France, pp. 279-292.

Dar, G.H., Tandon, S.M., 1987. Response of a cattle dung methane fermentation to nickel. Biological Wastes 22, 261-268.

Egginton, G.M., Smith, K.A., 1986. Nitrous-oxide emission from a grassland soil fertilized with slurry and calcium nitrate. Journal of Soil Science 37, 59-67.

Elzing, A., Monteny, G.J., 1997. Ammonia emission in a scale model of a dairy-cow house. Transactions of the ASAE 40, 713-720.

Keck, M., 1997. Ammonia emission and odour thresholds of cattle houses with exercise yards. In: Voermans, J., Monteney, G.-J. (Eds.), Ammonia and Odour Emissions from Animal Production Facilities. NVTL, Rosmalen, Vinkeloord, The Netherlands, pp. 349-354.

Misselbrook, T., Hansen, M., 2001. Field evaluation of the equilibrium concentration technique (JTI method) for measuring ammonia emission from land spread manure or fertiliser. Atmospheric Environment 35, 3761-3768.
Misselbrook, T.H., Pain, B.F., Headon, D.M., 1998. Estimates of ammonia emission from dairy cow collecting yards. Journal of Agricultural Engineering Research 71, 127-135.

Monteny, G.J., Erisman, J.W., 1998. Ammonia emission from dairy cow buildings: a review of measurement techniques, influencing factors and possibilities for reduction. Netherlands Journal of Agricultural Science 46, 225-247.

Monteny, G.J., Schulte, D.D., Elzing, A., Lamaker, E.J.J., 1998. Conceptual mechanistic model for the ammonia emissions from free stall cubicle dairy cow houses. Transactions of the ASAE 41, 193-201.

Mosier, A., 1989. Chamber and isotope techniques. In: Andrea, M., Schimmel, D. (Eds.), Exchange of Trace Gases between Terrestrial Ecosystems and the Atmosphere. Life Sciences Research Report 47. Wiley, Chichester, pp. 175-187.

Svensson, L., 1994. A new dynamic chamber technique for measuring ammonia emissions from land-spread manure and fertilizers. Acta Agriculturae Scandinavica Section B-Soil and Plant Science 44, 35-46.

Varel, V.H., Nienaber, J.A., Byrnes, B.H., 1997. Urease inhibitors reduce ammonia emissions from cattle manure. In: Heber, A. (Ed.), Ammonia and Odour Emissions from Animal Production Facilities, Proceedings. Nederlandse Vereniging Techniek Landbouw, Rosmalen, pp. 721-728.

Velthof, G.L., Brader, A.B., Oenema, O., 1996. Seasonal variations in nitrous oxide losses from managed grasslands in The Netherlands. Plant and Soil 181, 263-274.

Whitehead, D., 1995. Grassland Nitrogen. CAB International, Wallingford.

Yamulki, S., Jarvis, S.C., Owen, P., 1999. Methane emission and uptake from soils as influenced by excreta deposition from grazing animals. Journal of Environmental Quality 28, 676-682. 